\title{
LINGUISTICS
}

DOI: https://doi.org/10.33739/2587-5434-2020-3-11-18

\section{TOOLS FOR THE EXPRESSION OF THE MEANING OF "NEGATION" IN WORD-BUILDING OF THE GERMAN LANGUAGE}

\author{
Irina Kruashvili \\ Doctor of Philology, Associate Professor \\ Sokhumi State University \\ (Tbilisi, Georgia) \\ e-mail: i.kruashvili@sou.edu.ge
}

\begin{abstract}
Annotation. The aim of the article is to describe, what word building tools express negation in modern German language; to determine the place and importance of word-forming elements expressing negation in the German word building system; to characterize the internal structure and semantics of formations expressing negation; to describe the inventory of prefix derivatives expressing negation, to classify them according to formal and semantic parameters.

The article uses several methods of research. Namely, analysis of direct constituents, methods of descriptive, comparative, substantial and disjunctive opposition. The use of mentioned methods make the formal and semantic structure of word building constructions transparent.

Results of the research can be described as follows: the article analyzes more than one hundred word building constructions expressing negation, fetched from lexicographical sources, journals and newspapers, fiction literature and other samples of the functional style. The article reviews the inventory of prefix derivatives having negative word building meanings, there are described their structural and semantic characteristics. The corpus of formations expressing negation is compared to the headwords of dictionaries of the German language and there are revealed the items that are not registered in dictionaries.

We can make a conclusion from the materials analyzed in the article that prefixes represent very productive word building tools to express negation in the German language. The nominative function of prefix derivatives that express negation is to modify already existing words. They almost do not participate in compression of syntax constructions. During prefixation there occurs determination of the substantive or adjective root form by a morpheme prefix. Foreign (borrowed) prefixes expressing negation are mainly used in scientific special field texts, which is quite opposite for the German prefixes that mainly occur in the vocabulary of everyday conversation.
\end{abstract}

Keywords: word-building, negation, meaning, prefix, derivation

\section{СРЕДСТВА ВЫРАЖЕНИЯ СЛОВООБРАЗОВАТЕЛЬНОГО ЗНАЧЕНИЯ «ОТРИЦАНИЕ» В НЕМЕЦКОМ ЯЗЫКЕ}

\author{
Ирина Круашвили \\ Доктор филологии, ассоциированный профессор \\ Сухумский государственный университет \\ (Тбилиси, Грузия) \\ e-mail: i.kruashvili@sou.edu.ge
}

\begin{abstract}
Аннотация. Цель статьи - описать, какие словообразовательные средства выражают отрицание в современном немецком языке; определить место и значение словообразовательных элементов, выражающих отрицание, в немецкой словообразовательной системе; охарактеризовать внутреннюю структуру и семантику образований, выражающих отрицание; описать инвентарь префиксальных
\end{abstract}


производных, выражающих отрицание, классифицировать их по формальным и семантическим параметрам.

В статье используется несколько методов исследования, а именно: анализ по непосредственно составляющим, сравнительный, сопоставительный, трансформационный методы, субституционный анализ, метод дистинктивной оппозиции. Использование указанных методов делает прозрачной формально-семантическую структуру словообразовательных конструкций.

Результаты исследования можно охарактеризовать следующим образом: в статье проанализировано более ста словообразовательных конструкций, выражающих отрицание, которые взяты из лексикографических источников, журналов, газет, художественной литературы и других функциональных стилей. В статье рассмотрен инвентарь префиксальных производных, имеющих отрицательные словообразовательные значения, описаны их структурно-семантические особенности. Корпус образований, выражающих отрицание, сравнивается с заголовками словарей немецкого языка и выявлены элементы, не зарегистрированные в словарях.

Из проанализированных в статье материалов можно сделать вывод, что приставки представляют собой весьма продуктивные словообразовательные средства для выражения отрицания в немецком языке. Номинативная функция префиксальных производных, выражающих отрицание, заключается в модификации уже существующих слов. Они почти не участвуют в сжатии синтаксических конструкций. При префиксации происходит детерминация субстантивной или адъективной корневой формы приставкой. Заимствованные префиксы, выражающие отрицание, в основном используются в специальных научных текстах, что совершенно противоположно немецким префиксам, встречающимся в основном в лексике повседневного общения.

Ключевые слова: словообразование, отрицание, значение, префикс, деривация.

\section{INTRODUCTION}

Manifestation of the word building tools expressing negation occurs in word building constructions and that is why we have attempted to focus the formal, semantic and functional aspects of these constructions into the center of the research.

In order to express the meaning of negation, there are present a whole range of word building tools in the German language, namely, German and foreign (borrowed) prefixes, such as: un-, miss-, in-/i1-/im-/ir-, a/an-, de-/des-/dis-, non-. There must be noted the circumstances that all these prefixes are used with equivalent success both with nouns and with adjectives. Each of them has a more or less clearly expressed, independent meaning characteristic for just oneself. The general sema, which is characteristic only for them, expresses negation. In the present article, we shall characterize separately the word building elements expressing negation.

\section{REVIEW OF THE ISSUE}

Following the abundant wave of lexical units of the German language, intensiveness of the research of word building problems increases, which is attested by many articles devoted to these problems. The present article is based upon the theoretical works of German linguists as well as upon German lexicographical sources. Out of the legacy of those scientists, whose theoretical and methodological principles serve as a basis to the present article, we must name works of V. Fleischer (Fleischer 1983), V. Fleischer/I. Barz (Fleischer/Barz 2014), H. Elsen (Elsen 2013), E. Donalies (Donalies 2005), L. M. Eichinger (Eichinger 2000), J. Erben (Erben 2006), P. Eisenberg (Eisenberg 1998), H. Weinrich (Weinrich 1993) and others. The inventory of word building constructions is retrieved from lexicographical sources, namely, dictionaries of Duden (2011), Wahrig (2008), Muthmann (2011), etc. Some of the materials were fetched from the internet.

\section{METHODS OF RESEARCH}

The method of research must be well matched to the essence of the object, must show forth and clarify generalities characteristic for it. There are used several methods of research in this article, namely, analysis 
of the direct constituents, comparative, substantial and distinctive opposition. The use of the mentioned methods makes the formal and semantic structure of word building constructions transparent.

\section{RESULTS AND DISCUSSION}

In the German language, the most widespread tool for the expression of negative word building meaning is represented by un- prefix, which used to exist in its modern form yet in Gothic. A long history conditioned the fact that in modern German, formations with un- prefixes occur frequently. This prefix can produce negative forms of those adjectives that do not possess any unequivocal antonyms in dictionaries: ein unsterbliches Kunstwerk, ein unbequemer Stuhl.

Un- prefix is not characterized by combinatory limitations. It can be connected to both adjectival as well as participial basis (Duden 2006: 761). In case of adjectival basis, the basic word can be either onesyllable or two-syllable simplex: unfroh, unfrei, unklug, unzart, unedel, unwirklich, unsauber; or a suffix derivative: unabsichtlich, undankbar, ungastlich, unnarbig, unwörtlich, unvorsichtig, unglücklich, unschuldig, ungiftig, unbrauchbar, untauglich, unzweckmäßig, unmoralisch, unbürgerlich.

There are word building constructions that only occur in the un-prefixed negative form. Amongst them, formations with -bar, -lich and -sam suffixes are especially remarkable: unersättlich, unverkennbar, unaufhaltsam, unnahbar, unausrottbar, unausstehlich, unauslöschlich, unerforschlich, unzählig, unaufhörlich, unvergleichlich, unliebsam, unumstößlich. These formations can be considered as items yielded by min of circumfix and can be regarded as combinatory derivations: un- + . . -lich/-bar/-sam.

In modern German, the basis in the form of an independent adjective does not occur any more in such constructions as ungestüm (middle upper-Germanic gestüeme _ 'slow,' 'calm'), ungeschlacht (middle upperGermanic geslaht _ 'noble'), unbändig (middle upper-Germanic bendec _ told about a dog that is easy to be walked with a rope 'bant'), unbedarft (Dutch unbedarve _ 'naive'), unentwegt (Swiss entwegt _ 'restive') (Fleischer 1983: 290).

The basic word can be a composite in un- prefixed derivatives. Then, in V. Fleischer/I. Barz's opinion, -un- element can become an infix: kochunfertig, verkehrsuntauglich, lebensunwert, arbeitsunwillig, verhandlungsunfähig. (Fleischer/Barz 2014: 352).

Words with -un prefix, composing these formations, exist as independent adjectives, too: unfertig, untauglich, unfähig, hence, the mentioned constructions could be considered as composites consisting of a noun and an -un prefixed adjective. Yet, V. Fleischer /I. Barz substantiate their opinions on discussing the $u n$ - element as an infix by the fact that in view of the semantic relationship, there occurs the negation of the contents of the whole composite, e.g., entscheidungs(un)freudig (ibid).

In our opinion, in some cases -un- cannot be regarded as an infix. For instance, dienstunbrauchbar, kreuzunglücklich, todunglücklich. If we consider that -un- is an infix in these constructions, then there should exist the words: dienstbrauchbar, kreuzglücklich, todglücklich, which are not registered in modern German. What about the un- element before the composite, in V. Fleischer/I. Barz's opinion, it is blocked (exceptions: unselbstkritisch, unzurechnungsfähig) or negates only the first constituent: unwahrheitsfähig - der Unwahrheit fähig (Fleischer/Barz 2014: 352).

Neither here can we completely agree with the authors, as there are present the whole range of constructions, where the un-prefix does not negate only the first compositional member, but the whole formation: undienstfertig, unbußfertig, unbauwürdig, unfolgerichtig, unvollzählig, unzweideutig. In these constructions the first constituent does not occur as the independent word at all (*Undienst, *Unbu $\beta$, *Unbau). So, we cannot say für Undienst fertig, für Unbuß fertig or der Unbau würdig. We must understand the given derivatives as such: nicht bußfertig, nicht zweideutig (Kruashvili 2013: 175).

Similar constructions are: ungleichnamig, ungleichförmig, unfreiwillig, unzeitgemäß, ungleichzeitig, with just one difference that ungleich, unfrei, Unzeit exist as independent words, too. Yet, in these constructions as well as in the above-cited derivatives, un- prefix does not only negate the first direct constituent, but the whole construction: the meaning of ungleichförmig is not ungleich + förmig, but: nicht 
gleichförmig; that of ungleichzeitig is not ungleich + zeitig, but nicht gleichzeitig, analogically: unfreiwllig nicht freiwillig unzeitgemäß - nicht zeitgemäß, ungleichnamig - nicht gleichnamig.

In order to express negation, simultaneously to the un-prefix, in the German language, the element of frequency nicht- is used more and more often. It, as distinct from $u n$-morpheme, always stands before the composite: nichtarbeitsfähig, nichtpausfähig, nichtvollberechtigt, nichtberufstätig. The nicht- element occurs with suffix derivatives, too: nichtkapitalistisch, nichtsozialistisch, nichtflektierbar, nichteuropäisch.

Unlike neutral nicht- morpheme, un- prefix expresses a negative attitude towards the norm. Absence of features is considered as a deviation from the norm, pejorative assessment: eine nichtästhetische Einstellung ('unaesthetic opinion') - ein höchst unästhetischer Anblick ('a very unaesthetic (disgusting) picture'); die nichtchristlichen Einwohner ('non-Christian population') - ein sehr unchristliches Verhalten ('a very non-Christian (brutal, non-merciful) deed'); eine nichtberechenbare Kurve ('an unexpected bend') ein unberechenbarer Charakter ('an unpredictable character').

This can explain the circumstances that $u n$ - prefix cannot produce all the negative adjectives. Unprefix is destined mainly for those adjectives that are connected to a certain norm (e.g. social, ethical or esthetical). The simple, affirmative form of the adjective that is sometimes strengthened by the wohlmorpheme, expresses the meaning corresponding to the norm, and un-prefixed negative form, the meaning opposing the norm: eine sichere Argumentation ('a convincing argumentation') - eine unsichere Argumentation ('an uncertain, questionable argumentation'); ein ziemlich erfreuliches Ergebnis ('quite a pleasant (happy, joyful) result') - ein ziemlich unerfreuliches Resultat ('quite an unpleasant result').

As we have already mentioned, un- prefix is mainly connected to those simple adjectives that do not possess a unit of clearly expressed opposite meaning: undicht, unedel, unsicher. If un- prefix does not occur with the simple basis, this can be explained by the fact that this position is blocked lexically, for instance: lang - kurz (*unlang), jung - alt (*unjung). Only rarely does the un-prefix occur with simple adjectives that are matched by lexical antonyms. In such cases the $u n$-prefixed formations express the opposite meaning: richtig - falsch/unrichtig, gut - schlecht/ungut.

Due to the fact that in such cases $u n$ - prefixed adjective expresses negation of the affirmative adjective with its form and so acquires another nuance of the meaning, rather than a lexical antonym, it is less clearly defined and, accordingly, expresses less categoricalness. For instance, if while characterizing a conduct of a person we use the form unfein, the norms of politeness are less violated than with the use of the adjective grob. The logical difference between two types of antonymy, namely, contradictory (mutually exclusive) and contrary (opposite) antonymy rely upon the mentioned structural generality. H. Weinrich distinguishes them in such a way:

Affirmative adjective
ein kluger Einwand
ein gutes Gefühl
schöne Kleidung

$$
\begin{aligned}
& \text { Contradictive negative } \\
& \text { adjective } \\
& \text { ein unkluger Einwand } \\
& \text { ein ungutes Gefühl } \\
& \text { unschöne Kleidung }
\end{aligned}
$$

Contrary lexical antonym ein dummer Einwand ein schlechtes (böses) Gefühl hässliche Kleidung

(Weinrich 1993: 1012).

P. Eisenberg discusses the two mentioned types of antonymy in a different way. He cites the adjectives lang - kurz, as a sample of contrary antonymy, and words - lebendig and tot as the examples of contradictory antonymy (Eisenberg 1998: 240).

Adjectives - lebendig and tot - are so called classificatory notions. they are not subjected to gradation. While using them, we conclude that an object is either alive or dead; non-alive is the same as dead and vice versa; exactly such a usage is the characteristic sign of contradictory or mutually exclusive antonymy. What about lang and kurz, quite the opposite, they undergo gradation. If a road is not long, it is not necessary that it must be short and vice versa; a road can be neither long nor short. This feature is a sign of contrary or 
opposite antonymy. In P. Eisenberg's opinion, with un- prefix there are formed both types of couples of antonymic adjectives according to the meaning of the basis. The author cites the following examples:

Contrary antonyms: unglücklich, unklar, unklug, unehrenhaft, unleidlich, unschön, unzüchtig.

Contradictory antonyms: ungiftig, unleserlich, unfruchtbar, unbewaldet, ungesalzen, unverheiratet, unbepflanzt (Eisenberg 1998: 240).

The prefix un- is sometimes competed by the -los morpheme: ein untreuer Freund - ein treuloser Freund ('an untrue friend'); ein ungefährlicher Plan - ein gefahrloser Plan ('a harmless plan'); ein unwirksames Medikament - ein wirkungsloses Medikament ('a non-effective medication'); unschuldig sein schuldlos sein ('one is not guilty, innocent'); eine unabsichtliche Kränkung - eine absichtslose Kränkung ('unintentional offence'); unglücklich verliebt sein - glücklos lieben ('unlucky love').

Yet, there are cases when the prefix and suffix derivatives expressing negation do not overlap, are characterized with different meanings and cannot be substituted by one another: eine unhaltbare Theorie ('a weak theory (which cannot stand the criticism') - ein haltloser Mensch ('an unrestrained man'); ein unwilliger Blick ('a dissatisfied, offended glance') - ein willenloses Geschöpf ('a weak-willed creature'); ein unhandlicher Staubsauger ('an uncomfortable, unpractical vacuum cleaner') - ein handloser Mensch ('a handless man'); ein uneheliches Kind ('an illegitimate child') - ehelos leben ('an unwed cohabitation'); unappetitlich angerichtetes Essen ('a tastelessly served meal') - appetitlos essen ('to eat without appetite'); eine unförmige Gestalt ('a disproportionate body') - eine formlose Masse ('a formless mass').

Basic word figuring in un- prefix derivatives often represents a participial adjective: unbewiesen, unbeobachtet, ungeöffnet, ungezwungen, ungewaschen, unbefriedigend, unbedeutend, unerzogen, ungesalzen, unbeachtet.

If participle II represents the basic word, which serves as a predicate member together with bleiben, lassen, finden, then un-prefix implements the syntaxial function of the negative nicht element in the sentence: Die Theorie bleibt unbewiesen. Er lässt die Schuhe ungeputzt.

When a participle is used as an attributive, $u n$ - prefix still occurs parallel to the nicht element: eine nicht bewiesene/unbewiesene Theorie.

Un- prefixed participial forms get rather distant from the sphere of verbs. Such constructions acquire a clearly expressed adjectival character: der unbestimmte Artikel, mit unverdrossenem Fleiß, ein unvorbereiteter Prüfling.

Un- prefix is often associated with a foreign basis. Duden's Universal Dictionary (DUW) enlists up to 80 such adjectival derivatives: unakademisch, untypisch, unzivilisiert, and so on. $70 \%$ of them have German suffixes and are assimilated: unbürokratisch, unappetitlich, undeklinierbar. Only 30\% of the derivatives have a suffixless foreign basis: unfair, unfit, uncool, or are combined with foreign suffixes: undiskutabel, unkonventionell.

As we can see, $u n$ - prefix is characterized by the same meanings in all constructions. It has an only sema-negation.

Miss- prefix also serves to the expression of negation. It is relatively rare in German and occurs in the adjectives, which are derived from nouns having the same suffix: die Missgunst-missgünstig, der Missmut - missmutig, die Missfarbe - missfarben, missfarbig, or before the participial adjectives: missvergnügt, missgelaunt, missgestimmt, missgestaltet, missgewachsen, missgebildet, misstönend.

Sometimes an adjective with a miss- prefix can be connected both with a miss- prefixed noun as well as with a verb:

der Míssbrauch - missbráuchen - missbräuchlich.

der Missfallen - missfállen - missfäälig.

das Mísstrauen - misstráuen - mísstrauisch.

In such cases there occurs the alteration of accents. Miss- prefix in nouns and adjectives is accented, and in verbs, unaccented. It is connected exactly with unaccented verbal miss- prefixes that in the adjectives: 
missráten, missglǘckt, misslúngen - the mentioned prefix is uunaccented, as distinct from the abovementioned constructions.

Miss - prefix is rarely connected with an adjective: missbehaglich, misslaunig, misszufrieden. Missprefix contains a sema of negation and, at the same time, by pejorative tint, expresses deviation from the norm: missgünstige Kollegen, ein misstönender Pfeifton, der missratene Sohn, ein missglückter Versuch.

Sometimes miss- prefix can be regarded as a synonym of un- prefix expressing negation: misszufrieden - unzufrieden, missbehaglich - unbehaglich. Yet, derivatives with miss- and un- prefixes, having the same basis, sometimes acquire distinct semantic loads: missgünstige Kollegen ('envious colleagues') - ein ungünstiger Zeitpunkt ('an unfavourable moment').

In the expression of negation, like we have mentioned above, foreign prefixes participate, too.

$a$ - prefix, which occurs before the vowels in the form of an- variant, is relatively rarer. It is mainly used in texts connected with this or that scientific field, such as neutral-evaluative negation: anorganisch, arrhythmisch, amikroskopisch, amethodisch, afokal, agrammatisch, aseptisch, akatholisch, but they sometimes occur in everyday conversational language, too: amoralisch, analphabetisch, amusisch, alogisch.

Most part of $a$-/an-prefixed constructions include international lexemes and exist in other European languages, too, in forms of internationalisms: asozial, areligiös, anormal, atonal, anational.

Quite often, un- prefix is used with the same meaning: ein apolitischer (unpolitischer) Mensch; ein amoralischer (unmoralischer) Lebenswandel; ein atypischer (untypischer) Krankheitsverlauf. yet, sometimes there takes place a semantic differentiation: ein asozialer Charakter ('asocial character') - unsoziale Mieten ('taxes directed against the interests of the socially unprotected layer of population').

Prefixes de-/des-/dis- contain negative semes: disharmonisch is transformed as nicht harmonisch ('disharmonious = non-harmonious') (Donalies 2005: 108). In the sphere of adjectives, these prefixes are less widespread. They mainly occur in the texts pertaining to various fields of science. Basic word can be both ordinary as well as participial adjectives: disharmonisch, dezentral, devital, disloyal, disproportioniert, desinteressiert, diskontinuierlich, disproportional, desorientiert, desintegriert. In all the formations having the mentioned prefixes there are simultaneously present the tints of pejorative assessment: ein disharmonisches Verhältnis, ein desinteressierter Partner.

In- prefix also contains a negative sema, which can occur in the forms of il-, im-, ir- variants, according to the phoneme, with which the adjacent adjective begins. Im- prefix variant stands in front of $b, p$ and $m$ phonemes: immobil, immateriell, impotent, immanent, and $i l$ - and $i r$-variants, in front of $l$ and $r$ phonemes: illegitim, irreal, illiberal, illegal, irregular, irrational, irrelevant, irreparabel.

In- prefix with its variants is linked only with multi-syllable foreign words: inaktiv, intolerant, indiskret, inconsequent, indelikat, inkomplett, informell, inhuman, inakzeptabel, ineffektiv, incompetent, immoralisch. Only in the form of expressions there are present similar word-formations with German basic words: inegal, infundiert. Derivatives containing in-/il-/im-/ir-prefixes are often used in scientific field texts, but they do occur in the language of universal language, too: ein inoffizieller Besuch, ein illegitimes Verlangen, ein irreales Vorhaben, ein impertinentes Benehmen.

$U n$ - German prefix has synonymic meanings: inaktiv - unaktiv. In this connection, the following circumstances are important: un- prefix is more often connected to the German basis, and in-/ il-/ im-/ irprefixes, to the foreign one. Thus, we have the following pairs: immobil - unbeweglich, illegitim unrechtmäßig, intolerant - unduldsam, inconsistent - unbeständig, indeterminiert - unbestimmt.

Non- prefix is even less widespread than other foreign prefixes expressing negation: nonverbal, nonkonformistisch, nonchalant.

\section{CONCLUSION}

In the word building system of the German language, an important place is occupied by the word building tools expressing negation. The negative sema is contained by the prefixes, by means of which there occurs the negation of a given value by the basic word. As prefix derivatives reveal a high degree of 
motivation, it does not represent an outstanding difficulty to understand them. The word building system of the German language gives an opportunity to foreign or borrowed words and morphemes to be inculcated easily upon the system of the language. Presence of foreign prefixes expressing negation is the best example of this. Words yielded by means of them point to the fact that there is going on a process of internationalization of the German language. Structural and semantic classification of the derivatives presented in the article; approaches elaborated during their interpretation as well as practical recommendations will be of certain use for the readers interested in German word building.

\section{REFERENCES}

Donalies, E. (2005): Die Wortbildung des Deutschen. Ein Überblik [The word formation of the German. Overview], Tübingen, "Günter Narr Verlag".

Duden (2006): Die Grammatik [grammar], in 12 volumes. Volume 4, Mannheim et. al. „Bibliographishes Institut \& F. A. Brockhaus AG“.

Duden (2011). Deutsches Universalwörterbuch [German Universal Dictionary], Mannheim, "Bibliographisches Institut".

Eichinger, L. M. (2000). Deutsche Wortbildung. Eine Einführung [German Word-Formation. Introduction], Tübingen, „Narr“.

Eisenberg, P. (1998). Grundriss der deutschen Grammatik. Das Wort. [Outline of German Grammar. The Word], Vol. 1, Stuttgart, Weimar, "Metzler".

Elsen, H. (2013). Problemzonen der Wortbildung und der Eintrag im Wörterbuch [Problem areas of word formation and the entry in the dictionary]. In: Klosa, Annette (Hg.): Wortbildung im elektronischen Wörterbuch [Word formation in the electronic dictionary]. Tübingen, "Narr Francke Attempto Verlag". p.p. $87-104$.

Erben, J. (2006). Einführung in die deutsche Wortbildungslehre [Introduction to German word formation theory]. Berlin, „Schmidt“".

Fleischer, W. (1983). Wortbildung der deutschen Gegenwartssprache [Word formation of the German contemporary language], Leipzig, "VEB Bibliographisches Institut".

Fleischer, W./Barz, I. (2012): Wortbildung der deutschen Gegenwartssprache [Word formation of the German contemporary language], Berlin/Boston, „De Gruyter”.

Kruashvili, I. (2013). zedsarthauli sitkvatsarmoebithi konstruqtsiebis tsarmoqmnis tendentsiebi germanul enashi [Development tendencies of adjectival word building construktions in the German language ], Tbilisi, "Universali".

Muthmann, G. (2011). Rückläufiges Deutsches Wörterbuch [Reverse Dictionary of the German language]. Berlin, „De Gruyter“.

Wahrig (2008). Deutsches Wörterbuch [German Dictionary]. Gütersloh/München, "Bertelsmann”.

Weinrich, H. (1993): Textgrammatik der deutschen Sprache [Text grammar of the German language], Mannheim, „Dudenverlag“.

https://www.duden.de/woerterbuch [12.09.2020].

\section{For citation:}

Kruashvili, I (2020). Tools for the expression of the meaning of "negation" in word-building of the German language // International Scientific-Pedagogical Organization of Philologists "WEST-EAST" (ISPOP).

Scientific Journal WEST-EAST. Vol 3 N1 (October, 2020). pp. 11-18. https://doi.org/10.33739/2587-54342020-3-11-18 


\title{
Для цитирования:
}

Круашвили, И. (2020). Средства выражения словообразовательного значения «отрицание» в немецком языке // International Scientific-Pedagogical Organization of Philologists " WEST-EAST " (ISPOP). Scientific Journal WEST-EAST. Vol 3 N1 (October, 2020). C. 11-18.

https://doi.org/10.33739/2587-5434-2020-3-11-18

\section{Information about the author:}

Irina Kruashvili - $\mathrm{PhD}$, associate Professor for German linguistics at Sokhumi State University (Tbilisi), Scholarship holder of the DAAD and the Goethe-Institut, member of the Senate of Sokhumi State University, member of the German Teachers ' Association in Georgia (DVG), member of the International Association for German Studies (IVG), author of more than 50 scientific publications in German, English, Russian and Georgian. (Georgia).

e-mail: i.kruashvili@sou.edu.ge

\section{Сведения об авторе:}

Ирина Круашвили - доктор филологии, ассоциированный профессор Сухумского государственного университета (Тбилиси), стипендиат DAAD и Гете-Института, член Сената при Сухумском государственном университете, член Ассоциации Учителей немецкого языка в Грузии (DVG), член Международной Ассоциации Германистики (IVG), автор более 50 научных публикаций на немецком, английском, русском и грузинском языках (Грузия).

e-mail: i.kruashvili@sou.edu.ge

Manuscript received: 14/08/2020

Accepted for publication: $14 / 09 / 2020$

Рукопись получена: 14/08/2020

Принята к печати: 14/09/2020

\author{
International Scientific-Pedagogical Organization of Philologists "West-East" ISPOP \\ SCIENTIFIC JOURNAL "WEST-EAST" \\ ISSN (print) - 2587-5434 ISSN (online) - 2587-5523
}

